Katarzyna Laskowska

\title{
TERRORISM IN RUSSIA - MECHANISMS OF DEVELOPMENT AND A STRATEGY TO COUNTER IT
}

\section{The evolution of Russian terrorism}

Terrorism has been present as a phenomenon in Russia's social and political life for a long time. This is confirmed by the fact that as early as the 16th century, there were legal provisions in Russia addressing this problem. The adoption of such provisions had certainly been related to the frequent political killings of dignitaries and tsarist officials. In the centuries that followed, these events resulted in the tsars and the magnates terrorizing the subjects. In the 19th century, Russian terrorism was thought to have certain distinct features: it was nationalistic, revolutionary, and extremely reactionary ${ }^{1}$

Contemporary terrorism constitutes a threat to the security of the whole international community. This complex phenomenon has different characteristics in different countries, depending on the country's history, size, variety of domestic problems, the capacities of the state to counter and combat terrorism and the difficulties it has in doing so. Russia's unique characteristics are particularly salient due to the country's complex and often tragic history that shaped the specific relations between the society and the authorities that lead to numerous serious conflicts.

The subject of this paper is terrorism in Russia. In order to understand its essence, one must define the term "terrorism" as it pertains to Russia, its evolution and genesis, the reasons for its growth, and its goals and types. This will make it possible to discover the tendencies of this phenomenon. Then, one must discuss the scope of the specific actions aimed at preventing and fighting terrorism. This approach to studying Russian terrorism will make it possible to understand the growth mechanisms and to determine the strategy of countering terrorism in Russia.

1 В.В. Лунеев, Ю.М. Антонян, Терроризм [в:] В.Н. Кудрявцев, В.Е. эминов (ред.), Криминология, Москва 2005 , c. 335. 
Thus, one can say that before the October Revolution, terrorism was a manifestation of the objection of certain persons and organizations to tsarist Russia's political regime and the methods of governance, as well as an expression of religious and national conflicts which were oftentimes related to the division of the territory, the zones of influence, and the political interests. ${ }^{2}$ Examples of acts of terrorism in that period include the attempt to kill Alexander II and the assassination of the prime minister of the government, P.A. Stolypin, in 1911. In the following years, on the one hand, the concessions of the tsar and his government in response to the terrorist acts and, on the other hand, ruthless punishment of perpetrators in public view made this method of exerting pressure on the authorities quite popular. The impact of terrorism was heavy not only among the Social-Revolutionary party members and anarchists, but also among social democrats. Remarkably, W. Lenin stated that he "never renounced terror." In the fall of 1905, Lenin forced the Bolshevik party to switch to mass terror, which he called guerilla warfare. The seed of revolutionary terror fell on fertile soil and it became a mass phenomenon. The tsarist regime responded with repressions in the form of death penalty, deprivation of liberty, exile to penal colonies, ban on inhabiting certain locations, ban on holding specific offices or performing specific activities, expelling the perpetrators from universities, banning them from entering the country or leaving it. ${ }^{3}$

After 1917, Russia was a proving ground for unique forms of political and ideological terrorism: revolutionary (red) and counter-revolutionary (white) terrorism during the revolution and the ensuing civil war; domestic state terrorism in the period of Stalin's political repressions; state international terrorism in the period of rule of Soviet authorities. These forms were not criminalized during their occurrence and were not considered by the society and the state as political terrorism until the collapse of the socialist system. ${ }^{4}$

State terrorism in the Soviet period, especially during the Stalin era, was monstrous. In order to conduct it, the Soviet state established a unique system of administration of justice aimed at the destruction of political opponents. Millions of people died or suffered repressions for political reasons. According to W.W. Luneev, approximately 40 million people in that period were victims of repressions. ${ }^{5}$ The society was terrorized with the hideous, albeit effective, methods of the totalitarian system aimed to crush people to the extent that they were unable to oppose the

In the years 1902-1907, the SR's (socialists-revolutionaries) and other terrorists committed 5,500 acts of terror in Russia, to include assassinations of ministers, members of the State Duma, military police officers, police officers, and public prosecutors. See: О.М. Хлобустов, Терроризм в современной России, www. nasliedie. ru (access on 14 March 2006).

3 Д.И. Дзюба, Некоторые аспекты террористического опыта борьбы с терроризмом в России [в:] А.И. Долгова (ред.), Организованный терроризм и организованная преступность, Москва 2002, с. 80-83.

5 В.В. Лунеев, Преступность XX века. Мировые, региональные и российские тенденции, Москва 1997, с. 187-189. 
cruel government. Thus, Soviet citizens hardly ever employed terrorist attacks. Nevertheless, in the 1970's and 1980's the Soviet government reported several such acts: 1973 - an explosion of an airliner flying from Moscow to Chita; 1978 - a series of explosions in the Moscow subway; 1982 - hijack of an airliner flying to Turkey; 1983 - hijack of an airliner from Tbilisi airport and an attempt on the life of the 1st Secretary of the Communist Party and other leaders. ${ }^{6}$

In the period of Perestroika (the second half of the 1980's), and the ensuing period of social, political, and economic transformation, terrorist activities only intensified. They actually occurred on a mass scale, especially since the early 1990's, due to the multiple political, separatist, nationalist, and religious events that took place both in Russia and the neighboring post-soviet states, such as Azerbaijan, Armenia, Georgia, Tajikistan, and Uzbekistan. These events inevitably influenced the situation in Russia. The terrorists were successful in conducting their attacks thanks to the support they frequently received from other countries. Consequently, domestic terrorism in Russia became intertwined with international terrorism. ${ }^{7}$

One must remember the complex domestic situation in the Soviet Union in the fall of 1991 when the legally-elected Supreme Council of the Republic of Chechnya was disbanded. This act signified the taking away of the power by the Chechen National Congress from an elected organ as a result of mass riots and violent actions. On 27 October 1991, an election was held in Chechnya for national government bodies and for the office of the President of the Republic. The will to become independent and separate from Russia lead in the following years to exacerbation of the situation and even to warfare. Therefore, with time, terrorist-type groups, which operated both in Russia and outside of its borders, became more and more active. The Russian authorities began to treat members of such groups as terrorists and fight them intensively (as they still do). ${ }^{8}$ The terrorist attacks that ensued in response to the actions by the Russian government (in particular the Russian Army) involved hostage taking (Budionovsk - 1995, Pervomaiskoye - 1996) as well as more violent and better organized attacks (the attack on the Dubrovka theater in Moscow in 2002 and on the Beslan school in 2004).

Nonetheless, Russians themselves are not sure what to think about the events in Chechnya. For instance, the legal acts of the State Duma and the Council of the Federation use the following terms: mass riots, illicit actions involving the use of violence, illicit armed groups (in the criminological sense related to combating crime), armed conflict, war in the territory of the Republic of Chechnya, and

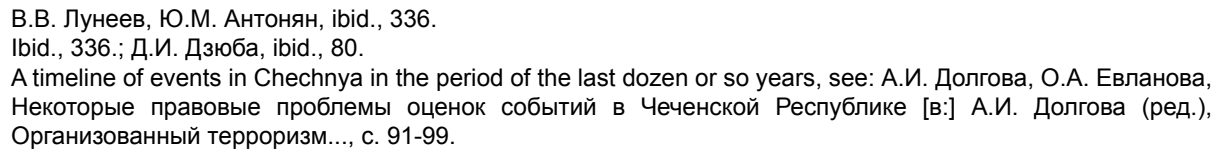


prisoners of war (in the military sense). While the events that took place in the Republic of Chechnya in the years 1991-1994 were perceived as criminal acts and countering of operations of illegal armed groups, those between December 1994 and 1998 are considered as warfare. ${ }^{9}$ Official Russian documents did not use terms such as fight for national liberation or fight for the independence of the Chechen nation. With time, the events in Chechnya were more and more often described as terrorism and the war was defined as counterterrorist operations. ${ }^{10}$

\section{The definition of terrorism in Russia}

As the above discussion indicates, terrorism in Russia has a centuries-long tradition. Over the years, the meaning and the scope of the term changed. An analysis of the history of anti-terrorist laws in Russia shows that the term "terrorism" is defined in three acts: the penal code of $1996^{11}$ which, in art. 205, defines terrorism as: the perpetration of explosion, fire, or other acts causing the risk of death of people, significant material damage, or occurrence of socially dangerous consequences, if such acts are effected with the aim of breaching public security, intimidating the society, or influencing decisions of authorities, as well as a threat to perpetrate such acts with such aims. The act of 27 July $2006^{12}$ changes the term used to describe such crimes from "terrorism" to "acts of terror." The legislator, in art. 205 of the Penal Code, defines the term as: the perpetration of an explosion, fire, or other acts that intimidate people and cause a risk of human death, significant material damage or occurrence of other serious consequences, with the aim of influencing decisions of authorities or international organizations, as well as a threat to perpetrate such acts with such aims. As we can see, the definitions of terrorism and of terrorist acts (as crimes) are nearly identical; the Act of 1998 on combating terrorism ${ }^{13}$ which, in art. 3 , defines terrorism as: violence or threat of violence towards natural persons or organizations and destruction or threat of destruction of property and other material objects that causes a risk of human death, significant material damage, or occurrence of other socially dangerous consequences, perpetrated with the aim of breaching public security, intimidating people, influencing state authorities to make decisions that are advantageous to the terrorists, or of achieving their illicit financial and (or)

А.И. Долгова, Конкретизация понятия терроризма в криминологических и правовых целях, Уголовное право 2003, № 2, с. 100 .

In April 2009, the Russian government decided to stop the counter-terrorist operation in Chechnya.

Уголовный кодекс Российской Федерации с 13. 06. 1996, Российская газета 1996, № 113-115.

12 Федеральный закон Российской Федерации от 27.07.2006 № 153-Ф3 «О внесении изменений в отдельные законодательные акты Российской Федерации в связи с принятием федерального закона «О ратификации Конвенции Совета Европы о предупреждении терроризма» и федерального закона «О противодействии терроризму», Российская газета 2006, № 4131 1998, № 31, Ст. 3808. 
other interests; an attempt to kill a state or social activist perpetrated with the aim to stop his or her state or other political activity or as a retribution for such an activity; an attack against a representative of a foreign state or an employee of an international organization who is provided international protection and against official premises or means of transportation of persons covered by international protection, if such deeds are perpetrated with the aim of provoking war or complicating international relations. This act is no longer in force; the act of 2006 on countering terrorism ${ }^{14}$ which, in art. 3 (1) defines terrorism as: an ideology and practice of influencing the decision making of state authorities, local authorities, or international organizations, which involves intimidating the society and (or) other forms of illicit acts involving the use of violence. The act includes a definition of a terrorist act which is analogous to that provided in art. 205 of the Penal Code.

As the above definitions of terrorism in legal acts indicate, only the act of 2006 defines the term. A.S. Kulikov and J.S. Romashev find this definition of terrorism to be correct. They believe that the legislator rightly regarded terrorism not only as the totality of crimes of terrorist nature, but also as a dangerous social phenomenon, with its key elements being a certain ideology and practice, founded on the use of violence, intimidation, and efforts to exert illicit influence on the decisions made by authorities so as to achieve certain advantages. ${ }^{15}$ J.G. Baybakov and W.D. Ivanov ${ }^{16}$, on the other hand, point to certain shortcomings of this definition. They believe that it consists in identifying the ideology of violence as an obligatory characteristic of terrorism. They support their claim by saying that violent acts can also be perpetrated without such ideological motives, e.g. as a revenge or to liberate leaders of criminal groups detained by law enforcement agencies. ${ }^{17}$

Now, it is necessary to define the scope of a criminological definition of terrorism. To do so, an analysis has been performed of definitions of terrorism formulated by Russian criminologists. The analysis has lead to the identification of characteristic features of the phenomenon:

- acts involving violence (physical or mental) or a threat to use it, ${ }^{18}$

- demonstration of influence on state authorities by striving to achieve goals defined by terrorists, ${ }^{19}$

\footnotetext{
14 Федеральный закон с 06.03.2006, № 35 - Ф3 «О противодействии терроризму», Собрание законодательства РФ 2006, № 11, Ст. 1146.

15 А.С. Куликов, Ю.С. Ромашев, О новом российском антитеррористическом законе, Государство и право 2007, № 7, с. 40-49.; Ю.А. Дмитриев, О противодействии терроризма, Государство и право 2006, № 10, с. 38.

16 Ю.Г. Байбаков, В.Д. Иванов, Комментарий федерального закона «О противодействии терроризму», Ростов на Дону 2006, с. 19-20.

17 Ibid., 20.

18 А.А. Матвеева, Терроризм [в:] Н.Ф. Кузнецова (ред.), Криминология, Москва 2006, с. 127.; А.И. Долгова (ред.), Преступность в России начала XXI века и реагпрование на неё, Москва 2004, с. 65.; Я.И. Гилинский (ред.), Девиантность, преступность, социальный контроль. Избранные статьи, Санкт-Петербург 2004, с. 301. 
- intimidation and suppression of both political opponents and competitors and the society, ${ }^{20}$

- performance of criminal plans, ${ }^{21}$

- socially dangerous acts, ${ }^{22}$

- criminal acts. $^{23}$

As the above characteristics indicate, terrorism, in the criminological sense, can be defined as acts involving the use of violence (physical or mental) or the threat to use it, aimed at intimidating authorities and the society so as to achieve certain goals (e.g. political, economic, religious, or ideological). This definition encompasses both the goals and the methods of such crimes, while indicating the danger paused by such acts to the society.

An analysis of the definitions, both from the legal and from the criminological point of view, shows that they have the following common elements that constitute an essence of terrorism: the use of violence, the intimidation of the society, and the illicit influence on the decision of authorities.

\section{The causes of terrorism in Russia}

As the history of Russian terrorism shows, the causes of this phenomenon are related to the complex political, social, and economic situation of the country over the centuries. The causes have been analyzed by both criminologists ${ }^{24}$ and analysts ${ }^{25}$ of the problem who have divided them into political, economic, and social causes and emphasized their internal and external character.

Because terrorism most often springs from political motives, it is the political causes that will be discussed first. The political causes of terrorism in Russia include the difficult and complex situation of the Russian state, especially after the collapse of the Soviet Union. It was at that time that new political movements, parties, fronts, and organizations with different political views emerged and tried to control the government. ${ }^{26}$ This has lead to political pluralism, a new phenomenon in Russia. The situation resulted in more intense fighting between the numerous parties representing

Ibid., 433.

В.Д. Малков, (ред.), Криминология, Москва 2004, с. 298.; А.И. Долгова, Терроризм и организованная преступность [в:] А.И. Долгова (ред.), Организованный терроризм..., с. 3.

В.Н. Кудрявцев, преступность и нравы переходного общества, Москва 2002, с. 225.; А.И. Долгова, Конкретизация понятия..., с. 101.

А.В. Гыскэ, Современная российская преступность и проблемы безопасности общества. Политический анализ, Москва 2000, с. 223.

е.g. В.В. Лунеев, А.И. Долгова, А.А. Матвеева.

e.g. А.В. Гыскэ.

А.В. Гыскэ, ibid., 225. 
the interests of various social groups. This has lead to the worsening of relations between the different nations within the Russian Federation, the strengthening of religious hate and animosity ${ }^{27}$, and was conducive to the occurrence of ethnic conflicts. ${ }^{28}$ National minorities began to strive to become sovereign and enjoy the benefits of their own culture, tradition, and government. ${ }^{29}$ Criminologists point to the importance of the "Chechen factor" and the "Islamic factor" and of the related activities of foreign terrorist organizations. They emphasize the tendency of Islamic activists to propagate their religion and to increase its influence. ${ }^{30}$ One of the political causes of the growth of terrorism in Russia is also the war in Chechnya (especially in the years 1995-1996) where terrorist acts became a part of regular warfare. ${ }^{31}$

The economic and social situation in Russia has also had a significant impact on the growth of terrorism in Russia. The political transformation of the early 1990's has lead to a profound economic crisis and to sharp inequalities of wealth in the society. ${ }^{32}$ The misguided policies of the government have lead to a drop in the social protection of the society ${ }^{33}$. This was reinforced by the process of globalization of the social relations which has lead to the creation of an ideology of the poor fighting against the rich (the state, the government, and the individuals). ${ }^{34}$ Thus, social antagonisms arose and parts of the society became hostile to one another. The society took efforts to protect their interests by supporting separatist tendencies. ${ }^{35}$ Some social groups were ready to use violence (to include terrorism) to solve their problems and to satisfy their needs. ${ }^{36}$ The lack of mechanisms of social control greatly facilitated such actions.

One can say that the background of the social and economic causes of terrorism in Russia is mainly the existence of multiple unsolved social and economic problems. Such problems easily transformed into conflicts between the different nations of the Federation. The society had the sense that the weak government was building barriers to separate itself from the people and engaging in ineffective transformation ${ }^{37}$ and that its authority and trust was not strengthened by the mass media which propagated violence as a means of solving issues. ${ }^{38}$ The media often referred to Russia's history and tradition where violence and terror used to achieve political objectives were

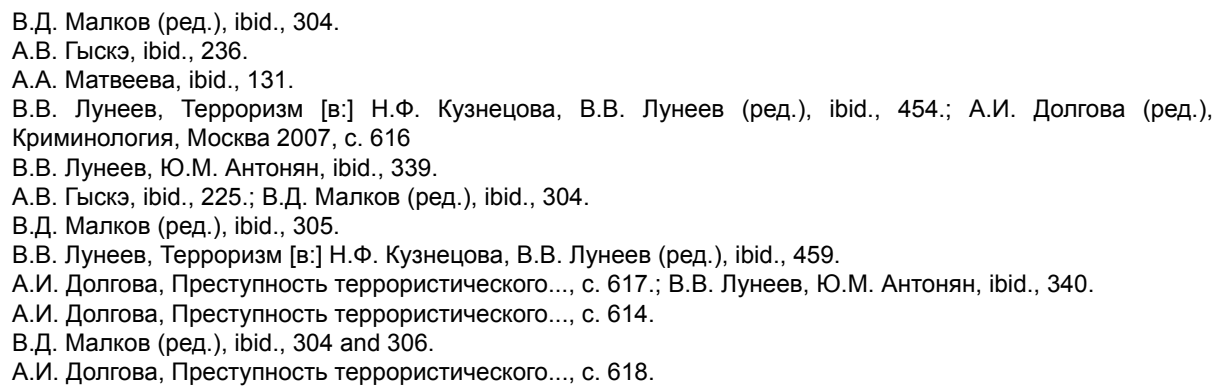


commonplace. ${ }^{39}$ This complex situation was reinforced by the collapse of the system of spiritual and moral values as well as legal awareness. This was particularly important because, as Russian criminologists emphasize, support for terrorism in the Russian society is very salient. ${ }^{40}$ This is not completely true because some Russians express their support not of terrorism but of the Chechen's struggle for national liberation.

It should also be highlighted, that Russia has a large pool of people who may potentially join terrorist groups. They include former soldiers, former special services operatives, and former combatants who are well-prepared for difficult tasks. ${ }^{41}$ It is them who often form and lead organizations that use weapons and explosives. ${ }^{42}$

What supports the growth of terrorism in Russia is also, as some say, a complete lack of control over the market for weapons and explosives which are used for acts of terror and over the market for drugs which are largely sold illegally to finance illegal activities. ${ }^{43}$

Other causes include the problem of poor effectiveness of the combat against terrorism in Russia, which is due to the shortcomings of the operation of law enforcement (low detection rate) and administration of justice (difficulties with proving guilt), and the inadequacy of the adopted programs, strategy, and laws. ${ }^{44}$

\section{The tendencies in terrorism in Russia}

Over the years, terrorism in Russia has been transformed. New types and features emerged and the threats posed by terrorism changed and increased.

W.W. Luneev and J.M. Antonyan ${ }^{45}$ distinguished the following types of terrorism present during the different periods of the Russian state:

- political terrorism - related to the fight for power and directed to intimidate political opponents. The activities of the SR's and the activists of "Narodnaya Volya" can be classified in this type;

Ibid., 305-306.; В.В. Лунеев, Ю.М. Антонян, ibid., 340 and 344.

В.В. Лунеев, Ю.М. Антонян, ibid., 341.

Ibid., 342.

В.Д. Малков (ред.), ibid., 305.

А.И. Долгова, Преступность террористического..., с. 618.

Ibid., 618.; В.Д. Малков (ред.), ibid., 306.; K. Laskowska, Rozwój antyterrorystycznego ustawodawstwa w Federacji Rosyjskiej [Development of anti-terrorist laws in the Russian Federation] [in:] K. Indecki, ed., Przestępczość terrorystyczna. Ujęcie praktyczno-dogmatyczne [Terrorist criminal activity. Practical-dogmatic approach], Poznań-Białystok-Łódź 2006, 104-118.

В.В. Лунеев, Ю.М. Антонян, ibid., 332-333. 
- state terrorism - aiming to fully subordinate the society to the government, to destroy and eliminate those who oppose the state and are hostile to it. This type of terrorism was present in the USSR;

- religious terrorism - aiming to recognize and elevate one religion, one church, and to weaken the influence of other religions. According to W.W. Luneev and J.M. Antonyan, this type of terrorism is currently present in Chechnya. However, one must say that qualifying the events in Chechnya as religious terrorism is probably wrong and proves the misunderstanding of the essence of the Chechnya conflict among Russians;

- nationalistic terrorism - aiming to degrade one nation and to deprive it of power and national dignity. According to W.W. Luneev and J.M. Antonyan, the current Chechen separatism is a manifestation of this type of terrorism.

They refer to the attack on the Dubrovka theater to emphasize that this separatism has nothing to do with patriotism;

- criminal terrorism - one that is closely related to illicit profits and power achieved through the destruction of competitors with violence and threats. It is manifested in the contemporary activities of organized criminal structures who use such methods; ${ }^{46}$

- ecological terrorism - one that encompasses a wide range of activities: from actions by radical political "green" organizations through those by groups striving to take over nuclear power installation. Such terrorism is currently used, among others, by ecologists; ${ }^{47}$

- cyber terrorism - one using the most advanced information technologies for terrorism-related purposes, especially to obstruct the operation or to damage the infrastructure of a state. This type of terrorism can nowadays pose a threat to the Russian state;

- nuclear terrorism - one consisting in illegal use of nuclear energy and radioactive materials to achieve terrorism-related goals. ${ }^{48}$ This type of terrorism can nowadays be a threat to the Russian state.

Each of the above types of terrorism poses specific threats to the society and the state, which result from its objectives and the character and effects of the measures used. Russian criminologists believe that the key goals of contemporary terrorism

46 В. Замковой, М. Ильчиков, Терроризм - глобальная проблема современности, Москва 2006, с. 50; В.В. Лунеев, Организованная преступность, организованный терроризм в условиях глобализации, Социологические исследования 2002, № 5, с. 62 и др.; K. Laskowska, Rosyjskojęzyczna przestępczość zorganizowana. Studium kryminologiczne [Russian-speaking organized crime. A criminological study], Białystok 2006, 205-214.

47 В. Морозов, В. Пушкарев, Экологический терроризм, понятие, сущность, квалификация, Уголовное право 2007 , № 2, с. 122-124.

48 К.И. Косачев, Ядерный терроризм и международно-правовые механизмы борьбы с ним, Государство и право 2004 , № 8, с. 85-94 
in Russia are: to change the political regime and the policies of the state, to break the territorial integrity of the Russian state, to disrupt the national government, to force the government to make concessions, to provoke a war or an armed conflict, and to establish new (national, religious) standards in social relations. ${ }^{49}$ These goals are achieved by using any of the various means and measures that are effective in triggering off fear and anxiety through the use of violence or its threat and taking advantage of the mass-media. ${ }^{50}$ This leads to destabilization of the state, loss of health and life of people, exposure to radioactive and toxic materials, and financial losses. ${ }^{51}$ It may also lead to a large number of victims (dead or ill).

According to A.A. Matvieyeva ${ }^{52}$, contemporary terrorism in Russia is characterized by severity of acts of terror, uncompromising attitudes of terrorists, use of state-of-the-art technologies, global reach $^{53}$, increase in the number of terrorist acts, complex organization and extensive conspiracy of the activities, and difficulties with forecasting terrorist acts. An important feature of terrorism is also determined by its links to organized crime, which is a source of financing. This is important because terrorists need money to pay mercenaries who perpetrate acts of terror, to prepare and arm them, to provide transportation, to arrange terrorist bases and camps, and to recruit new persons. ${ }^{54}$

Thus, as W.W. Luneev ${ }^{55}$ rightly emphasizes, recent years were a period of growth with regards to the organization and the financial and material backing of terrorism and the scale of its consequences. W.W. Luneev substantiates his view by presenting the results of his analysis of over ten spectacular acts of terrorism that took place in the recent years. Some examples of such acts include:

- 14 April 1995 - attack on Budionovsk,

- 19 March 1999 - bombing in Vladikavkaz,

- 9 September 1999 and 13 September 1999 - bombing of residential houses in Moscow,

- 9 May 2002 - bombing in Kaspiysk,

- 23-26 October 2002 - attack on the Dubrovka theater,

В. Д. Малков (ред.), ibid., 299

Ibid., 300 .

Ibid., 301.

А.А. Матвеева, с. $130-131,133-134$.

In earlier times, terrorism was not directed at everyone, whereas nowadays it is intended to intimidate everyone. See: P.X. Макуев, Терроризм в условиях глобализации, Государство и право 2007, № 3, с. 44.

54 А.И. Долгова, Преступность террористического..., с. 612.; Е.А. Степанова, Роль наркобизнеса в политэкономии конфликтов и терроризма, Москва 2005, с. 258-259.; Ю.И. Авдеев, А.Я. Гуськов, Проблемы организованности современного терроризма [в:] А.И. Долгова (ред.), Организованный терроризм..., с. 31. 
- 1 August 2003 - explosion of a truck with explosive materials in Mazdok (North Ossetia),

- 6 February 2004 - explosion in the Moscow subway,

- 31 August 2004 - explosion of a bomb in front of a Moscow subway station,

- 1-3 September 2004 - attack on the Beslan school.

All these events involved large numbers of casualties.

A unique tendency of contemporary terrorism is to cause as extensive damage as possible. Terrorists victimize people who are not involved in politics and have no influence on the key decisions of the state, which was evident in such attacks as those in Dubrovka and Beslan. The scale of terrorist attacks is larger and larger, which is due both to the links to organized crime (and its support with regards to financial backing, conspiracy, and organization of activity) and, as W.P. Zhuravliov emphasizes, to the higher intellectual and education level of the leaders. ${ }^{56}$

As W.W. Luneev and J.M. Antonyan indicate, terrorists in Russia have not formed one consolidated group but many groups, especially Chechen ones. Interestingly, none of them claim responsibility for terrorist attacks that have been perpetrated. Thus, one can conclude that terrorism in Russia has not split from traditional organized crime, has not become legalized, and has not been transformed into a separate structure of political terrorism. ${ }^{57}$

\section{Countering terrorism in Russia}

In an effort to develop a strategy to counter terrorism in Russia, one must point to the fact that the Russian legislator has defined the term of countering terrorism in art. 3 (4) of the act on countering terrorism. According to the definition, it is an activity of organs of the state government and the local governments consisting in:

- preventing terrorism, to include detecting and eliminating the causes of and the conditions conducive to the perpetration of acts of terrorism (prevention of terrorism),

- identifying, preventing, stopping, detecting, and investigating acts of terrorism (fight against terrorism),

- reducing and (or) eliminating the consequences of manifestations of terrorism.

\footnotetext{
56 В.П. Журавлёв, Терроризм и некоторые подходы к борьбе с ним [в:] А.И. Долгова (ред.), Организованный терроризм..., с. 48-49.

57 В.В. Лунеев, Ю.М. Антонян, ibid., 336.
} 
The legislator has determined the areas where efforts must be made, which include both prevention of and fight against terrorism. For that purpose, the legislator has also defined the duties of the individual state organs with regards to preventing terrorism. Pursuant to art. 5 of the act, the following organs are competent in this area: the President of the Russian Federation (establishing the policies of the state with regards to countering terrorism, defining the competences of the organs of the federal executive power), the Government of the Russian Federation (defining the competences of the organs of the federal executive power, organizing and implementing measures to minimize and eliminate the consequences an manifestations of terrorism), the organs of the federal executive power and organs of the state power of the constituent entities of the Russian Federation.

The Russian Armed Forces (art. 6) also play an important role in countering and combating terrorism as they may be quickly deployed counter-terrorist operations on land, sea, and in the air. ${ }^{58}$

The act also points to the involvement of the society in combating terrorism by defining, in art. 11, restrictions imposed on the population for the purpose and in the event of counter-terrorist operations. Therefore, the act provides for the payment of compensation to citizens who have suffered as a result of such an operation and for legal and social protection to persons involved in combating terrorism.

In order to achieve the assumptions of the 2006 act, the Russian government must undertake and perform a complete system of measures correlated with causes. This is why it is necessary to monitor and to systematically learn, study, and analyze the causes of terrorism. Such efforts must consist, most of all, of operational, informational, analytical, and prognostic activities. ${ }^{59}$

Because Russia's security system is not fully ready to counter terrorism, the actions taken are inadequate and delayed due to the ineffective operation of its organizational structures and the use of the same schemes for various manifestations, scales, goals, and motives of terrorism, ${ }^{60}$ the need for restructuring is more than evident.

As W.W. Ustinov emphasizes, one must remember that a strategy to combat terrorism should be comprehensive, not linked to any specific threat, long-term, and specific with regards to the needed reforms to be implemented in stages, according to their priority. Such a strategy must involve the whole nation, as opposed to the

\footnotetext{
58 The need to widen the competences of the Armed Forces in anti-terrorist operations was emphasized by: Д.В.Гордиенко, Опыт борьбы вооружённых сил с терроризмом в Российской Федерации, Государство и право 2001, № 1, с. 75-78.

59 Ibid., 347.

60 А.Г. Чернов, Проблемы борьбы с терроризмом в Чеченской Республике [в:] А.И. Долгова (ред.), Организованный терроризм..., с. 63.
} 
government only, and reflect and consider terrorist threats in the context of other threats to national and international security. ${ }^{61}$

Effective ways of countering and fighting terrorism in Russia will also require stringent control of storage and trade of firearms, ammunition, and explosives, as well as radioactive, chemical, and biological materials. The state must also face the big challenge of discovering and eliminating sources of financing of terrorism. It should also take steps to establish an effective system of educating the society in the spirit of respect for other cultures, religions, and traditions of the different peoples living in this multi-ethnic country. The Russian government must also strive to resolve the religious, ethnic, and economic problems that are at the roots of terrorism. It is necessary to broaden international cooperation on various levels, including exchange of information and joint activities of special forces aimed at intensifying the fight against terrorism. ${ }^{62}$

What I. Trunov proposes is that in order to encourage the Russian populace to actively participate in combating terrorism, it is necessary to establish a legal mechanism for paying for information on crimes and acts of terrorism submitted by citizens, similar to systems adopted in other countries (e.g. the prize for capturing Bin Laden). ${ }^{63}$

Based on the above discussion, one can say that Russia is aware of the gravity of the threat posed by terrorism and undertakes many actions to eliminate or limit it. Nevertheless, effective implementation of adopted solutions has been sabotaged by poor technical and psychological preparation of persons involved in anti-terrorist operations and by the scale of the threat. As it turns out, countering terrorism is not an easy task because, as J.I. Gilinskiy states, "there are no simple solutions to complex social problems." ${ }^{64}$

\footnotetext{
61 В.В. Устинов, Государственная антитеррористическая стратегия: общая концепция и правовые аспекты, Государство и право 2003, № 3, с. 7.

В.В. Лунеев, Ю.М. Антонян, ibid., 348-349.

И.Я. Трунов, Правовые основы борьбы с терроризмом, Уголовное право 2004, № 4, с. 92.

Я.И. Гилинский, ibid., 305.
} 


\section{TERRORYZM W ROSJI - MECHANIZMY ROZWOJU I STRATEGIA PRZECIWDZIAŁANIA}

W opracowaniu przedstawiono złożoność terroryzmu w Rosji. Dokonano tego poprzez ukazanie pojęcia omawianego zjawiska, jego fenomenu i przemian, a także podłoża jego rozwoju w tym kraju. $Z$ przeprowadzonych analiz wynika, że terroryzm w Rosji ma długą historię, sięgającą kilku wieków wstecz. U podstaw jego rozwoju leżały i leżą trudne do rozwiązania problemy polityczne i społeczno-ekonomiczne państwa rosyjskiego. Rodzą one różne nowe przejawy i rodzaje zjawiska, w tym terroryzm ekologiczny czy cyberterroryzm. Współcześnie zjawisko charakteryzuje drastyczność aktów, używanie nowych niebezpiecznych technologii, wzrost skali. Jako szczególnie niebezpieczne należy wskazać powiązania terroryzmu z przestępczością zorganizowaną. Zagrożenia te państwo rosyjskie próbuje ograniczać poprzez prawo i działalność organów ochrony porządku prawnego zajmujących się przeciwdziałaniem terroryzmowi oraz jego zwalczaniem. Jednakże ograniczenie jego skali jest przedsięwzięciem trudnym. Rozwiązanie tego problemu wymaga zarówno woli politycznej władz rosyjskich, jak też zmiany postawy społeczeństwa wobec zjawiska.

Key words:

Terrorism, Russia, acts of terror, legal regulations 